\title{
Role of Bank Characteristics in Determining the Effect of Non-financial Information Disclosure on Bank's Value on Tobin's Q Scale: An Applied Study on the Jordanian Commercial Banks
}

\author{
Hasan M. AL-Shatnawi ${ }^{1}$ \& Firas A.N Al-Dalabih ${ }^{2}$ \\ ${ }^{1}$ Department of Accounting, Irbid National University, Jordan \\ ${ }^{2}$ Department of Accounting Information System, Irbid National University, Jordan \\ Correspondence: Hasan M. AL-Shatnawi, Department of Accounting, Irbid National University, Irbid, Jordan.
}

Received: April 28, 2019

doi:10.5430/ijba.v10n4p46
Accepted: May 13, 2019

Online Published: June 17, 2019

URL: https://doi.org/10.5430/ijba.v10n4p46

\begin{abstract}
This study aimed at determining the role of bank characteristics in determining the effect of non-financial information disclosure on values of Jordanian commercial banks on Tobin's q scale. To achieve this goal, the study adopted the analytical descriptive research approach and analyzed the financial reports of the 13 Jordanian commercial banks listed on Amman Stock Exchange Market (ASEM) during the period 2014-2017. To test the hypotheses and achieve the study goal, the data were analyzed using simple linear regression analysis and hierarchical interaction regression analysis. Regression analysis revealed that all the studied commercial banks disclose the non-financial information according to the instructions of institutional governance of the banks. In addition, the analysis showed that there is a positive effect of non-financial disclosure on the values of banks on Tobin's q scale. Moreover, the results uncovered that the interaction effects of non-financial information disclosure and each of the size, growth, and profitability of the bank foster the positive effects of the individual variables on the values of the banks on Tobin's q scale. Meanwhile, the study found that the interaction effect of non-financial information disclosure and financial leverage does not affect the values of the banks on Tobin's q scale.
\end{abstract}

Keywords: non-financial information disclosure, Tobin's q scale, bank characteristics, Jordanian commercial banks

\section{Introduction}

The studies of Yuen et al. (2009), Cohen et al. (2012), Bachoo et al. (2013), Dima et al. (2013), Hahn and Michael (2013), and Haji and Hossain (2016) indicated that the current financial reports have to include non-financial information, along with the financial information, to satisfy the purposes of the stakeholders of loaners, investors, and consumers of the goods and services that those companies produce. In consequence, non-financial information disclosure in the financial reports will lead to production of high-quality information reports and creation of value for all stakeholders. This issue, therefore, required consensus among the information users who are interested in production, delivery, and use of the accounting information on making changes to the contents of the current financial reports mainly represented by increasing the disclosure of non-financial information to improve quality of the published information and raise the trust in them (i.e., the reports) and provide an added value for evaluation of the market value of the shares of the company. Doing so contributes to drawing of an integrated view of the ability of the company to create an added value for the stakeholders.

The value of the bank is regarded as one of the necessary information which the stakeholders in the exchange market need for taking several economical decisions related to performance of the bank in the market. Assessment of the value of the bank depends on several evaluation approaches that rely on the accounting information and on the international standards for preparation of the financial reports (Imam et al., 2013; Talkahn, 2017). The commercial banks face great pressure from the stakeholders with the purpose of increasing the level of non-financial disclosure due to their need for data and information that help them in taking their investment decisions. In general, the stakeholders depend to a great extent on this information, which they derive from various sources, most important of which is the financial reports.

Due to importance of non-financial disclosure in increasing reliability of anticipation of the future performance of the banks, the Central Bank of Jordan issued the Amended Instructions of Corporate Governance for Banks No. 
63/2016 Dated 1 September 2016 (hereafter referred to as AICGB 63), which obliged the commercial banks to apply Article 22 (Disclosure and Transparency) of these instructions. Therefore, non-financial information disclosure is considered as an indicator of the level of success of the bank because as the level of disclosure of this information increases a positive impression about efficiency and effectiveness of bank performance develops among the stakeholders, which will lead to an increase in the market value of the bank. To the contrary, it is probable that the increase in the level of disclosure of non-financial information can represent a complication and perturbation element for the stakeholders when taking their decisions and estimating the market values of shares based on the financial reports (Coram, 2010; Cohen et al., 2012). So, this subject received attention of researchers and it was investigated in many studies like those of Flostrand and Strom (2006), Coram (2010), Cohen et al. (2012), Grewal et al. (2015), Al-Shoaar et al. (2015), Jahjooh (2017), and Alshatnawi (2018). However, the results of these studies are contradictory, where some studies uncovered presence of positive relationships among these variables (that is, bank characteristics, disclosure of non-financial information, and value of the bank on Tobin's q scale) while other studies indicated no relationship between them. Hence, this study sought to assess the role of the bank characteristics in determining the effect of non-financial information disclosure according to the AICGB 63 on values of the banks on Tobin's q scale, taking into consideration the differences between the banks in their sizes and levels of growth, financial leverage, and profitability.

\section{Research Problem}

A review of the literature brings to notice that the results of previous studies of effect of non-financial disclosure on the market values of firms are contradictory. For example, the studies of Yuen et al. (2009), Dima et al. (2013), Al-Shoaar et al. (2015), and Jahjooh (2017) indicated a positive effect of non-financial disclosure on the market value of the establishment whereas the study of Grewal et al. (2015) pointed to a negative effect. On the other hand, the studies of Coram (2010), Velazquez et al. (2013), and Al-Shatnawi (2018) showed that no statistically-significant relationship exists between non-financial information disclosure and the market value. Some studies (e.g., Flostrand and Strom (2006), Assahli (2011), Cohen et al. (2012), and Al-Shoaar et al. (2015)) revealed that there are certain factors that may have a role in the effect of non-financial disclosure on the market values of the shares. As a result of this controversy, and as the bank characteristics may have a role in the effect of non-financial information disclosure on value of the bank on Tobin's $q$ scale, this study aimed at examining the role of the bank characteristics in the effect of non-financial information disclosure according to the AICGB 63 on values of the banks on Tobin's $q$ scale in the Jordanian business environment. In view of this, the research problem can be summarized in the need for answering the following five questions:

1- What is the effect of the degree of non-financial information disclosure in accordance with the AICGB 63 on values of the banks on Tobin's q scale?

2- Does the effect of the degree of non-financial information disclosure according to the AICGB 63 on values of the banks on Tobin's q scale differ according to differences in sizes of the banks?

3- Does the effect of the degree of non-financial information disclosure according to the AICGB 63 on values of the banks on Tobin's q scale differ according to differences in levels of growth of the banks?

4- Does the effect of the degree of non-financial information disclosure according to the AICGB 63 on values of the banks on Tobin's q scale differ according to differences in levels of financial leverage?

5- Does the effect of the degree of non-financial information disclosure according to the AICGB 63 on values of the banks on Tobin's q scale differ according to differences in profitability of the banks?

\section{Research Objectives}

The objective of this research was to assess the effect of non-financial information disclosure according to the AICGB 63 on values of the banks on Tobin's q scale through an applied study of the Jordanian commercial banks listed on Amman Stock Exchange Market (ASEM) during the period 2014-2017. This objective can be realized by achieving the following subsidiary objectives:

1- Determining importance of non-financial information disclosure.

2- Specifying importance of bank value in terms of its concept and measures.

3- Identifying the effect of non-financial information disclosure on values of the banks on Tobin's q scale.

4- Determining the effect of non-financial information disclosure on values of the banks on Tobin's q scale according to differences in bank characteristics (size, growth, financial leverage, and profitability). 


\section{Research Significance}

Significance of this study mainly lies in that it provides empirical evidence on importance of non-financial information disclosure for values of the banks on Tobin's q scale and on role of bank characteristics on effect of this disclosure on value of the bank in the Jordanian business environment, which is an issue that did not receive a sufficient extent of research as evidenced by the fact that the applied studies which handled this relation in the Jordanian business environment are scarce. Additionally, this study derives significance from the fact that it is based on financial lists analysis, which is due to give more accurate results as regards role of non-financial information disclosure in the financial reports of the banks on their values. Moreover, this study, in the light of its results, is due to contribute to obligation of the banks listed on ASEM to systematically disclose non-financial information in their annual financial reports because of the positive influence of release of this kind of information on their market values on Tobin's q scale and on helping the report users in developing in-depth understanding of operation of the banks and anticipation of their future performance. Furthermore, this study is one of few studies worldwide that performed this sort of investigation taking into account differences between banks in their sizes and levels of growth, profitability, and financial leverage. Outcomes of this study will, consequently, contribute to rationalization of the decisions of the stakeholders of the banks owing to that they will uncover role of bank characteristics on effect of non-financial information disclosure according to the AICGB 63 on values of the banks on Tobin's $q$ scale.

\section{Research Hypotheses}

To achieve the research objectives and answer its questions, the following research hypotheses were formulated:

H01: The degree of non-financial information disclosure according to the AICGB 63 has no statistically-significant $(\alpha=0.05)$ effect on values of the banks on Tobin's q scale.

H02: The effect of the degree of non-financial information disclosure according to the AICGB 63 on values of the banks on Tobin's q scale does not differ significantly $(\alpha=0.05)$ according to differences in sizes of the banks.

$\mathbf{H}_{\mathbf{0 3}}$ : The effect of the degree of non-financial information disclosure, according to the AICGB 63 on values of the banks on Tobin's $q$ scale does not differ significantly $(\alpha=0.05)$ according to differences in levels of growth of the banks.

$\mathbf{H}_{04}$ : The effect of the degree of non-financial information disclosure according to the AICGB 63 on values of the banks on Tobin's $q$ scale does not differ significantly $(\alpha=0.05)$ according to differences in levels of financial leverage.

$\mathbf{H}_{\mathbf{0} 5}$ : The effect of the degree of non-financial information disclosure according to the AICGB 63 on values of the banks on Tobin's $q$ scale does not differ significantly $(\alpha=0.05)$ according to differences in levels of profitability of the banks.

\section{Research Limits}

The limits of this research are the following:

1- The research sample confined to the Jordanian commercial banks that are listed on ASEM during the period 2014-2017. As such, the study utilized the latest available financial reports of the banks in the study period.

2- This study confined to only the non-financial disclosure items in financial reports of the Jordanian commercial banks that are listed on ASEM. These items are based on a legal text, which is Article 22 (Disclosure and Transparency) of the AICGB 63.

3- The study confined to valuation of banks using Tobin's q as a market measure. Accordingly, reliability and generalizability of the results of this study are tied to its methodology, accuracy of the data it employed, and to Tobin's q approach to valuation.

\section{Related Studies}

Review of the literature unveils that various previous studies researched into disclosure from various perspectives such as transparency of disclosure and the factors governing extent of disclosure. For example, Assahli (2011) explored the degree of transparency of disclosure in the financial reports in Saudi Arabia and assessed influence of company size on the degree of transparency of disclosure. The study found that the degree of transparency of disclosure in Saudi Arabia was low and that company size had effect on transparency. In another example, Velazquez et al. (2013) examined the effects of each of the firm size, sector type, firm performance, indebtedness, and the geographic location of the firm on disclosure of financial and non-financial information on the Internet in Latin America, specifically in Argentina, Brazil, and Mexico. The study adopted the analytical descriptive research 
approach and found that the general level of disclosure in these countries was low and that there were no effects of the firm size, sector type, firm performance, indebtedness, and the geographic location of the firm on disclosure of financial and non-financial information on the Internet. In a related study, Al-Maryani et al. (2014) investigated disclosure and transparency within the international principles of corporate governance in the Iraqi companies. He also researched into effects of type and size of company on disclosure of information. The study found that the levels of disclosure and transparency in the financial reports were low and that type of the company had high effect on disclosure and transparency. Meantime, company size did not affect disclosure or transparency. In a local example, Barakah (2016) studied the effects of the determinants of the level of non-financial disclosure of the commercial banks listed on ASEM, which were 13 banks. To this end, the study followed the analytical descriptive research approach. The study found limited transparency in disclosure of the items of the obligatory disclosure opposed by fulfillment of transparency in disclosure of some voluntary disclosure items according to bank size.

Another group of the studies looked into effect of non-financial information disclosure on market values of companies in terms of their share prices. For instance, Banghoj and Plenborg (2008) looked into influence of the level of voluntary disclosure on the relationship between the current and future profits in Denmark and reported that the increase in the level of disclosure did not improve the relationship between profitability and the market values of shares. However, the study found that there was an increase in the level of disclosure with time. In another example, Coram (2010) studied effect of non-financial information disclosure on share prices from the perspective of professional and non-professional investors in Australia. The study found that there were differences in evaluations of share prices between the two groups of investors in the case when the information was positive while the negative non-financial information had no effect in the case of both groups of investors. In line with this, Cohen et al. (2012) sought to determine effect of voluntary disclosure of both financial and non-financial information on the market values of the companies listed on the Turkish bourse, and, in turn, on the investors' related decisions. The study followed the analytical descriptive approach. It found that there was still shortage in disclosure of information and that the level of non-financial disclosure differs with company size. Besides, the study found that voluntary disclosure did not have significant effect on the market values of the shares of the studied companies. Likewise, Dima et al. (2013) examined the degree of disclosure of non-financial information and its influence on the market prices of the Romanian companies listed on Bukharest bourse. This study found that disclosure of non-financial information had a positive influence on the market prices of the sample Romanian companies.

In a local study, Ashoaar et al. (2015) sought to identify the roles of profitability and indebtedness of companies in determining the influence of the level of non-financial disclosure on their market values following the analytical descriptive research approach. They found that the investigated companies disclose non-financial information. Further, the results indicated that there is a positive effect of the level of non-financial disclosure on the market values of companies. Moreover, the results uncovered that the interaction between the level of non-financial disclosure and profitability of the company increases the positive effect of non-financial disclosure on its market value. Meanwhile, the interaction between the level of non-financial disclosure and indebtedness of the company does not influence its market value. Furthermore, Grewal et al. (2015) explored extent of influence of obligatory non-financial disclosure on market reaction through changes in the market values of the companies during the period 2013-2014, with a focus on the requirements of the non-financial disclosure according to the European Union standards. The study followed the analytical descriptive research approach and found that the obligatory non-financial disclosure has a negative impact on the market values of the companies. The researchers explained this result by that the European Union standards may sometimes give a worse impression about the company in the future than it is.

Jahjooh (2017) conducted a study to assess the extent of abidance of the companies listed on Palestine bourse by all the items of the non-financial disclosure according to the requirements of disclosure in the Palestinian laws and regulations. The study was also intended to determine the influence of the level of non-financial disclosure on the market values of the companies listed on the bourse of Palestine. For achieving these goals, the study followed the analytical descriptive research approach. Data analysis disclosed that the level of non-financial disclosure in the studied companies was high and that the level of non-financial disclosure had no effect on the market values of the examined companies. Lastly, Alshatnawi (2018) explored the effects of degree of non-financial information disclosure on quality of the financial reports and on the market values of the Jordanian commercial banks. The study followed the analytical descriptive research approach. The study found that the sample commercial banks were disclosing non-financial information and that the degree of non-financial information disclosure had no effect on the market values of the commercial banks. As regards the control variables, the study found that bank size had a positive effect on the market values of the commercial banks while financial leverage did not. 
The present study is an extension of the previous studies. However, it is characterized by its research methodology, which corresponds to analysis of the financial report content in a recent time series. Further, a relevant scale was applied to measure the non-financial disclosure parameter according to Article 22 (Disclosure and Transparency) of AICGB 63. Moreover, the bank value was measured on Tobin's q scale. In addition, the study incorporated four essential characteristics of the banks, namely, bank size, growth, financial leverage, and profitability, so as to identify the roles of these characteristics in determining the effect of non-financial information disclosure on values of the banks on Tobin's $q$ scale, which are roles that none of the previous studies touched upon.

\section{The Theoretical Framework}

\subsection{Disclosure}

In its implementation of the disclosure function, the accounting profession faced big challenges when choosing the appropriate basis for accounting disclosure and specifying the most suitable disclosure method so as to enhance credibility of the accounting information and meet the needs of the information users to help them take the sound decision. With the high increase in economic growth in the world market, technological advancement, proliferation of the multi-national companies, globalization of the capital markets, emergence of new techniques in circulation of securities in the global financial markets - importance of disclosure was leveraged due to its provision of beneficial and trustworthy information for the information users about the financial position and business performance of the markets and helping the users of the financial reports in taking rational decisions. Therefore, the level of disclosure of information in the financial reports plays a vital role in reducing the state of uncertainty and bridging the information asymmetry gap, thus helping the stakeholders in evaluating firm performance objectively (Binh, 2012; Ashoaar et al., 2015).

To that end, in the recent year's interest grew in the subjects of transparency and disclosure, and the level of disclosure which the establishments demonstrate in their financial reports rose. In consequence, a wider variety of the other information started to appear in the financial reports of companies, other than the information appearing in the financial lists and the accompanying explanations, which the companies disclose in response to the needs and demands of the stakeholders for more additional information that contribute to improvement of the quality of the financial reports, and, in consequence, improvement of the quality of their decisions related to those companies (Abdol Gader, 2017). With respect to the situation in Jordan, and due to importance of the non-financial disclosure and the necessity of practicing transparency, the commercial banks were obligated to apply Article 22 (Disclosure and Transparency) of AICGB 63. This article included a number of basic items that must be disclosed. The basic items actually consist of 33 subsidiary items that must be disclosed according to the following statements (Central Bank of Jordan, 2018):

1- Item B of Article 22 of AICGB 63 states that the annual report of the bank must include a statement indicating that the council is responsible for (i) accuracy and adequacy of the financial data of the bank and the information contained in that report and (ii) the internal control and monitoring systems.

2- Item E of the same article stated that the Management Council has to ensure that the annual report includes what follows as a minimum:

2.1- A summary of the organizational structure of the bank.

2.2- A briefing of the tasks and responsibilities of the committees of the council, as well as any authorities which the council mandated to those committees.

2.3- The information of interest to the stakeholders, which are shown in the Bank Institutional Governance Manual, and the extent of commitment of the bank with content of this Manual.

2.4- Information about every member of the Management Council in terms of her/his qualifications and experiences; extent of her/his contribution to the capital of the bank; whether she/he is independent or not; membership in the committees of the council; her/his appointment date; any memberships which she/he occupies in the Central Bank of Jordan and the management councils of other companies; all forms of rewards granted by the bank to her/him, each separately, in the previous year; the loans endowed by the bank to her/him in the previous year; and any other transactions that took place between the bank and the member or the parties related to her/him.

2.5- Information about the Department of Risk Management in terms of its structure, nature of its operations, and evolving developments.

2.6- Information about the number of times of meeting of the Management Council, and the number of times of presence of every member in these meetings. 
2.7- Information about the names of every member of the council and senior executive management resigning during the year

2.8- A summary of the reward-granting policy in the bank, with disclosure of all forms of rewards granted to the members of the council, each separately, in the previous year and the rewards of all forms granted to the members of the senior executive management, each separately, in the previous year.

2.9- A listing of the names of the shareholders possessing $1.0 \%$ or more of the capital of the bank, with a clarification of whether any of these inputs is partially or totally mortgaged.

2.10- Statement by every council member that she/he did not obtain any benefits through her/his work in the bank in the past year without disclosing them.

\subsection{Market Value}

The market value of the bank is defined as the price or equivalent which the bank stakeholders see to be expressing its value. This value is the sum of the listed shares of the bank times their average price at the end of the financial period. That is, it is the number of bank shares at the end of the year multiplied by their closing prices (Bonna, 2012; Zalloom, 2013, Kareem, 2014, Al-Oadat, 2015; Abdol Naser, 2017). Therefore, the increase in the share price may reflect good bank value from the viewpoint of the shareholders (Tjia \& Setiawati, 2012; Al-Oadat, 2015; Abdol Naser, 2017). The market value is considered as a good measure that indicates efficiency of financial performance of the establishments. In this respect, there are many models that are used to estimate the value of the establishment that depend on market performance indicators like the share price, market value of equity to book value of equity, and Tobin's q (Liew et al., 2015; Abdol Naser, 2017). This research employed Tobin's q model for assessment of the values of the banks under study, which is the most accurate and applied model for estimation of the market values of companies.

\subsection{Tobin's $Q$}

Tobin's $q$ model is considered as one of the most accepted evaluation models due to ease of calculation and interpretation of Tobin's $q$ once using the right accounting and financial data. If Tobin's $q$ value is less than one, then the market value is less than the value of the assets of the bank, that is, the bank is underestimated. On the other hand, If Tobin's $q$ value is higher than one, then the market value is higher than the cost of replacing the assets of the bank. This is an indicator of good performance of the management, which means that there are better chances for investment in this bank. Tobin's $q$ value is the average market value of the assets relative to their replacement value. Due to difficulty of reaching to the replacement value of the assets, their book value is used (Bonna, 2012; Zalloom, 2013, Kareem, 2014, Al-Oadat, 2015; Abdol Naser, 2017).

\subsection{Non-financial Information}

The study of Jahjooh (2017) indicated that the non-financial information is more important than the financial information. This was reinforced by the criticisms directed to disclosure in the financial reports by the users of these reports, namely, lack of inclusion of some intangible assets in the financial position list such as the innovative services and products, the quality of products, and support of the knowledge and skills of the employees. As well, the studies of Radebaugh and Gray (2001) and Abdol Gader (2017) pointed to that disclosure is regarded as one of the quality features of the annual reports, and, in consequence, increasing the degree of disclosure of non-financial information in the annual report will achieve benefits for the establishment since this leads to increasing the transparency, reducing the information asymmetry among the stakeholders, and lowering the level of uncertainty of the stakeholders in relation to the decision-making process, and, in turn, increasing quality of the financial reports. So, the practice of non-financial disclosure by the bank, side-by-side with the financial disclosure in its financial lists, will positively reflect on its growth and profits. It will reflect positively on quality of its financial reports and on performance of the shareholders when evaluating the company, which will, eventually, increase its market value.

\subsection{Bank Characteristics}

Several variables influence the market values of the banks, most important of which are the size, growth, financial leverage, and profitability of the bank. To control the relationship between degree of non-financial information disclosure and values of the banks, these variables were incorporated in the present study. Bank size represents one of the characteristics that play fundamental role in determining the effect non-financial information disclosure on values of the banks on Tobin's $q$ scale as the small-sized establishments suffer from the problem of information asymmetry, contrary to the large-size establishments. Therefore, investment in the small-sized establishments is riskier. Bank growth represents ability of the bank to use its assets efficiently and achieve an income that enables it to 
pay off the creditors, increase its assets, and maximize the bank value and owners' profits (Ashshahed and Al-Anati, 2017).

Financial leverage measures extent of exposure of the bank to financial risks. Through maintaining balance between the degree of the risk associated with the increase in the size of debts, on the one hand, and benefiting from its advantages, on the other hand, the financing risk resulting from the increase in debts is reduced (Annajjar, 2013). The study of Ashoaar (2015) indicated that disclosure is one of the factors that help management of the company in obtaining financing of their financial needs faster and at a lower cost. When the extent of disclosure is unsuitable, the lending parties hesitate to provide the financial facilities.

Bank profitability is represented in the revenue resulting from the invested assets in the bank. It reflects ability of the bank to achieve a satisfactory rerun for the stakeholders. The study of Ashoaar et al. (2015) pointed to that profitability of the company may affect its market value because realizing a higher profitability is an indicator of efficiency of the management. When the profitability drops, the management hesitates to disclose detailed information in order to conceal the reasons of drop in profitability. Effect of this reflects on the market value of the company, even though some studies, e.g., Banghoj and Plenborg (2008), reported that the increase in the level of disclosure does not improve the relationship between profitability and the market value of the shares.

\section{Research Methodology}

To achieve the study objectives, the researchers adopted the descriptive analytical research approach. This section presents the research population and sample, definition and description of the study variables, and the study model.

\subsection{Research Population and Sample}

The study population is the Jordanian commercial banks operating in Jordan during the period 2014-2018, whose number is 25 banks, according to the Banks in Jordan Guide (Central Bank of Jordan, 2018). To select the study sample, a number of determinants were set, represented by availability of the annual financial reports for the banks over the study period and availability of all the data necessary for calculation of the variables of the study model. Foreign and Islamic banks were excluded because of the special nature of their non-financial disclosure. In the light of the aforementioned determinants, the study sample was 13 banks, representing $52.0 \%$ of the research population. The data were obtained from the websites of the sample banks and Jordan Securities Commission.

\subsection{Definition and Description of the Research Variables}

\subsubsection{The Independent Variable: Degree of Non-financial Information Disclosure}

The independent variable in this study is the degree of non-financial disclosure. The researchers developed an index for disclosure of the non-financial disclosure according to the study of Ashshatanawai (2018) that was based on Article 22 (Disclosure and Transparency) of the AICGB 63, which obliged the boards of directors of the commercial banks to prepare their financial lists, including a set of non-financial disclosures (Central Bank of Jordan, 2018). Based on this, the developed index of non-financial disclosure consisted of 33 items as shown in Appendix I.

To calculate the non-financial disclosure index, the researchers employed a binary scale as follows:

1- Allotting a degree of (1) if disclosure of the item was implemented in the financial report of the bank.

2- Assigning a degree of (0) if disclosure of the item was not implemented in the financial report of the bank.

The researchers followed the content analysis approach to determine the items which the banks actually disclosed, following the unweighted method, which was employed in many similar earlier studies (e.g., Omar and Simon (2011), Omar et al. (2014), Ashoaar et al. (2015), Barakah (2016), and Jahjooh (2017)). The following equation was used to calculate the non-financial disclosure index for each bank:

$$
\text { Non-financial Disclosure Index }=\left(\frac{\text { Number of disclosed items }}{\text { Sum of items applying to the bank }}\right) * 100 \%
$$

The lowest disclosure percentage is zero if the bank did not disclose any of the items that apply to it, while the highest percentage is $100 \%$ if the bank disclosed all the applying items.

\subsubsection{The Dependent Variable: Value of the Bank on Tobin's $Q$ Scale}

Value of the bank on Tobin's $q$ scale was calculated as the ratio of the market value of equity (number of traded shares times the market price of share, which is the closing price at the end of the accounting period) to the book 
value of the total assets as follows:

Tobin's $\mathrm{Q}=\frac{\text { (Number of shares of the bank by the end of the year * Their closing prices) }}{\text { Historical cost of the assets }}$

\subsubsection{Moderating Variables}

The moderating variables were:

\subsubsection{Bank Size}

Bank size is estimated as the natural logarithm of the total capital at the end of the year (Hossain, 2008; Barakah, 2016).

\subsubsection{Bank Growth}

Bank growth is the ratio of the sum of assets of the current year to that of the previous year (Ashshahed and Al-Anati, 2017).

\subsubsection{Financial Leverage}

The financial leverage is estimated as the ratio of the total obligations to the total assets at the end of the year (Molayjee, 2014; Abdoil Naser, 2017).

\subsubsection{Bank Profitability}

Bank profitability is calculated using the index of Return on Assets (RoAs) by dividing the net profit by the average assets (Velazquez et al., 2013; Ashoaar et al., 2015).

\subsection{Study Model}

Based on the study problem, objectives, and hypotheses, a model was developed to evaluate the effect of degree of non-financial information disclosure as an independent variable on bank value on Tobin's $q$ scale as the dependent variable. The study also employed some essential bank characteristics (bank size, bank growth, financial leverage, and bank profitability) as moderating variables as illustrated in Figure 1.

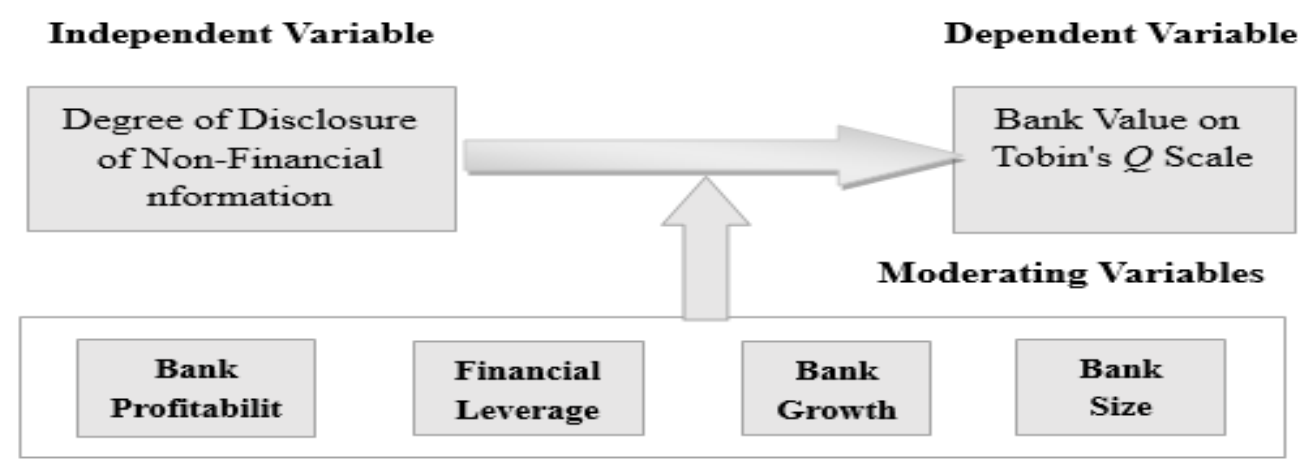

Figure 1. Study model

\section{Data Analysis and Results}

Analysis of the data progressed in three phases that started with ensuring goodness of the data for statistical analysis, followed by a description of these data, and ending with testing the research hypotheses. Following is a description of these phases.

\subsection{Testing Goodness of the Data for Statistical Analysis}

\subsubsection{The Normality Test}

The researchers used Kolmogorov-Smirnov test to examine if the data do, or do not, follow the normal distribution. The testing results are summarized in Table 1. 
Table 1. Results of Kolmogorov-Smirnov test of distribution of the study variables

\begin{tabular}{lll}
\hline \multirow{2}{*}{ Study Variable } & \multicolumn{2}{l}{ Kolmogorov-Smirnov Statistic } \\
\cline { 2 - 3 } B score & Sig. \\
\hline Bank Value on Tobin's $Q$ Scale & 1.320 & 0.124 \\
\hline Bank Size & 0.191 & 0.203 \\
\hline Bank Growth & 0.910 & 0.198 \\
\hline Financial Leverage & 1.232 & 0.379 \\
\hline Bank Profitability & 0.811 & 0.225 \\
\hline
\end{tabular}

Table 1 spotlights that the probability values for the study variables are greater than the level of significance (0.05), which suggests that these variables follow the normal distribution (Hair et al., 2010).

\subsubsection{The Multicollinearity Test}

Multicollinearity was tested through tolerance and the variance inflation factor (VIF) for each of the independent and moderating variables (Table 2) as these two measures are multicollinearity diagnostics.

Table 2. Results of testing for multicollinearity among the study variables

\begin{tabular}{lll}
\hline Variable & Tolerance & VIF $^{\mathbf{a}}$ \\
\hline Disclosure of Non-financial Information & 0.628 & 1.681 \\
\hline Bank Size & 0.671 & 1.521 \\
\hline Bank Growth & .8620 & 2.264 \\
\hline Financial Leverage & 0.598 & 1.810 \\
\hline Bank Profitability & 0.714 & 2.016 \\
\hline
\end{tabular}

a VIF: Variance Inflation Factor

It is seen in Table 2 that the values of the VIF did not exceed 10 (Field, 2005; Molayji, 2014) for any of the independent and moderating variables. Hence, the study data do not suffer from the multicollinearity problem as correlations among the variables are very low and not statistically significant.

\subsection{Descriptive Analysis of the Study Variables}

After the researchers confirmed goodness of the data for statistical analysis, they moved to the second phase of data analysis, in which a descriptive analysis of the study variables is performed (Table 3).

Table 3 presents descriptive statistics of the study variables for the 13 sample commercial banks listed on ASEM in the period 2014-2017. As regards the independent variable; bank value on Tobin's $q$ scale, Table 3 brings to light that the minimum Tobin's $q$ value was 0.071 for the Jordan Ahli Bank in 2016. On the other hand, the maximum Tobin's $q$ value was 0.324 for the Housing Bank for Trade and Finance in 2017. The mean bank value on Tobin's $q$ scale was 0.142. It is noticed that the bank value on Tobin's $q$ scale is less than 1.0 for all banks owing to dependence of the banks in financing their assets on individuals' deposits of their different types.

Table 3. Descriptive statistics of the study variables

\begin{tabular}{llllll}
\hline Variable & $\mathbf{N}^{\mathbf{a}}$ & Min. $^{\mathbf{b}}$ & Mean & Max. $^{\mathbf{c}}$ & S.D $^{\mathbf{d}}$ \\
\hline Bank Value on Tobin's $Q$ Scale & 52 & 0.071 & 0.142 & 0.324 & 0.064 \\
\hline Disclosure of Non-financial Information & 52 & 0.606 & 0.867 & 1 & 0.084 \\
\hline
\end{tabular}




\begin{tabular}{llllll}
\hline Natural Logarithm of Bank Size & 52 & 8.00 & 8.20 & 8.81 & 0.22 \\
\hline Bank Growth (\%) & 52 & -0.149 & 0.071 & 0.460 & 0.120 \\
\hline Financial Leverage (\%) & 52 & 81.71 & 86.14 & 90.72 & 2.41 \\
\hline Bank Profitability (\%) & 52 & 0.05 & 1.2 & 2.05 & 0.45 \\
\hline
\end{tabular}

${ }^{a} \mathrm{~N}$ : Number of observations

${ }^{b}$ Min.: Minimum value

${ }^{\mathbf{c}}$ Max.: Maximum value

${ }^{\text {d }}$ S.D: Standard deviation

In other respects, the minimum value for the independent variable; non-financial disclosure in the annual reports of the Jordanian commercial banks, was $60.6 \%$. This percentage of disclosure pertains to the Jordanian Arab Investment Bank in 2014. Meanwhile, the maximum percentage of non-financial disclosure in the financial reports of the commercial banks was 100\%. It relates to both the Union Bank and the Arab Banking Corporation in the year 2015. Meantime, the mean percentage of non-financial disclosure in the financial reports of the commercial banks was $86.7 \%$, which is suitable. This indicates that the current level of non-financial disclosure in the sample banks is satisfactory for providing the decision takers with useful information for making rational decisions. This result agrees with the findings of Barakah (2016) and Ashoaar et al. (2017). With respect to characteristics of the banks, the sizes of the banks ranged from 8 to 8.81 , with a mean of 8.20. This indicates that the total capital of the banks is very big. Regarding bank growth, variations between the banks in their growth rates are noticed. In specific, the maximum growth rate was 0.46 for the Jordanian Arab Investment Bank in the year 2015 while the minimum growth rate was 0.149 for the Jordan Commercial Bank in the year 2016. As to the financial leverage, it ranged from 81.71 to 90.72 , with a mean value of 86.14, which is high. It reflects dependence of those banks in financing their assets on the commitments. Regarding profitability, the analysis results disclose that the mean bank profitability was 1.2. Profitability of the bank measures extent of efficiency of the management in exploiting its resources to generate profits. A mean profitability of 1.2, which is low, means that the net profit represents $1.2 \%$ of the total assets of the bank. A profitability range as wide as $2.1(0.04-2.05$; Table 3$)$ uncovers wide variations in profitability between the sample banks.

\subsection{Hypothesis Testing Results}

$\mathbf{H}_{01}$ : The degree of disclosure of non-financial information according to the AICGB 63 has no statistically-significant $(\alpha=0.05)$ effect on values of the banks on Tobin's $q$ scale.

Table 4. Results of regression analysis of effect of non-financial information disclosure on values of the banks on Tobin's $\boldsymbol{q}$ scale

\begin{tabular}{llllll}
\hline Variable & $\boldsymbol{B}$ & Sig. & $\boldsymbol{F}$ & $\boldsymbol{R}^{\mathbf{2}}$ & Std. Error \\
\hline Constant & 12.224 & 0.003 & \multirow{2}{*}{9.380} & \multirow{2}{*}{0.538} & 1.420 \\
\cline { 1 - 3 } Disclosure of non-financial information & 4.321 & 0.000 & & & \\
\hline
\end{tabular}

This hypothesis was tested using simple linear regression analysis. The testing results (Table 4) indicate that non-financial information disclosure affects the values of the banks on Tobin's $q$ scale and that it explains about 53.8\% of the variations in the bank values. The value of the unstandardized model coefficient $(\beta)$ was 4.321, which means that effect of disclosure of non-financial information on the values of the banks on Tobin's $q$ scale is positive. The value of Sig. was less than 0.05 . This leads to rejection of the null hypothesis and acceptance of the alternative hypothesis. That is, the degree of non-financial information disclosure according to the AICGB 63 has a statistically-significant effect on values of the banks on Tobin's $q$ scale. The first regression equation can be formulated as follows:

\section{Tobin's $q=12.224+4.321 *$ NFDisc +1.420}

$\mathbf{H}_{\mathbf{0 2}}$ : The effect of the degree of non-financial information disclosure according to the AICGB 63 on values of the 
banks on Tobin's $q$ scale does not differ significantly $(\alpha=0.05)$ according to differences in sizes of the banks.

The second hypothesis tests differences in effect of non-financial information disclosure on values of the banks on Tobin's $q$ scale according to differences in sizes of the banks. In order to test this hypothesis, hierarchical interaction regression was employed.

As shown in Table 5, in the first phase of analysis, the non-financial information disclosure variable was entered. The results (Table 5) show that this variable has a statistically-significant effect on values of the banks on Tobin's $q$ scale $(F=9.380$, Sig. $=0.000)$ and that it explains $53.8 \%$ of the variations in values of banks.

Table 5. Results of regression analysis of effect of degree of non-financial information disclosure on values of banks on Tobin's $q$ scale according to differences in sizes of the banks

\begin{tabular}{|c|c|c|c|c|c|c|}
\hline \multirow[b]{2}{*}{ Variable } & \multicolumn{2}{|c|}{ First Stage } & \multicolumn{2}{|c|}{ Second Stage } & \multicolumn{2}{|c|}{ Third Stage } \\
\hline & $\boldsymbol{B}$ & Sig. & $\boldsymbol{B}$ & Sig. & $\boldsymbol{B}$ & Sig. \\
\hline Constant & 12.224 & 0.003 & 12.367 & 0.000 & 13.462 & 0.001 \\
\hline Disclosure of non-financial information & 4.321 & 0.000 & 4.651 & 0.000 & 4.021 & 0.002 \\
\hline Bank size & & & 7.598 & 0.000 & 8.527 & 0.000 \\
\hline Interaction between disclosure and bank size & & & & & 0.267 & 0.001 \\
\hline$R^{2}$ & & 0.538 & & 0.420 & & 0.510 \\
\hline$F$ & 9.380 & & & 8.124 & & 11.841 \\
\hline Sig. & 0.000 & & & 0.000 & & 0.001 \\
\hline Std. Error & 1.420 & & & 1.395 & & 1.414 \\
\hline
\end{tabular}

In the second phase of analysis, the bank size variable was entered. The results (Table 5) reveal has a statistically-significant effect of bank size on values of the banks on Tobin's $q$ scale $(F=11.8124$, Sig. $=0.001)$.

In the third phase of the analysis, the interaction between non-financial disclosure and the bank size variable was added. The results (Table 5) show a statistically-significant effect of that interaction on values of the banks on Tobin's $q$ scale $(F=11.841$, Sig. $=0.001)$. Consequently, the null hypothesis is rejected and the alternative hypothesis is accepted, that is, the effect of the degree of non-financial information disclosure according to the AICGB 63 on values of the banks on Tobin's $q$ scale differs significantly according to differences in sizes of the banks. The corresponding regression model can be formulated as follows:

\section{Tobin's $q=13.462+4.021$ NFDisc + 8.527 Bsize + 0.267 (NFDisc * Bsize $)+1.414$}

$\mathbf{H}_{\mathbf{0 3}}$ : The effect of the degree of non-financial information disclosure according to the AICGB 63 on values of the banks on Tobin's $q$ scale does not differ significantly $(\alpha=0.05)$ according to differences in levels of growth of the banks.

This hypothesis tests differences in effect of non-financial information disclosure on values of the banks on Tobin's $q$ scale according to differences in levels of bank growth. For testing this hypothesis, hierarchical interaction regression was used.

As shown in Table 6, in the first phase of hypothesis testing, the non-financial information disclosure variable was entered. The results uncovered that non-financial information disclosure has a statistically-significant effect on values of the banks on Tobin's $q$ scale $(F=9.380$, Sig. $=0.000)$ and that it explains $53.8 \%$ of the variations in values of banks.

Table 6. Results of regression analysis of effect of degree of non-financial information disclosure on values of banks on Tobin's $q$ scale according to differences in levels of bank growth

\begin{tabular}{llllllll}
\hline \multirow{2}{*}{ Variable } & \multicolumn{2}{c}{ First Stage } & \multicolumn{2}{c}{ Second Stage } & \multicolumn{2}{c}{ Third Stage } \\
\cline { 2 - 7 } & B & Sig. & B & Sig. & B & Sig. \\
\hline
\end{tabular}




\begin{tabular}{llllllr}
\hline Constant & 12.224 & 0.003 & 2.115 & 0.001 & 9.684 & 0.000 \\
\hline Disclosure of non-financial information & 4.321 & 0.000 & 3.521 & 0.000 & 5.202 & 0.000 \\
\hline Bank size & & & 6.215 & 0.002 & 4.741 & 0.000 \\
\hline Interaction between disclosure and bank size & & & & & -0.381 & 0.000 \\
\hline$R^{2}$ & & 0.538 & & 0.360 & 0.412 \\
\hline$F$ & 9.380 & & & 14.985 & 12.128 \\
\hline Sig. & 0.000 & & 0.002 & 0.000 \\
\hline Std. Error & 1.420 & & 1.112 & 1.127 \\
\hline
\end{tabular}

In the second phase of testing, the bank size variable was entered. Table 6 discloses a statistically-significant effect of the bank growth variable on values of the banks on Tobin's $q$ scale $(F=14.985$, Sig. $=0.001)$.

In the third phase of testing, the interaction between non-financial disclosure and bank growth was entered. The results (Table 6) indicate a statistically-significant effect of that interaction on values of the banks on Tobin's $q$ scale $(F=12.128$, Sig. $=0.001)$. Thereupon, the null hypothesis is rejected and the alternative hypothesis is accepted, i.e., the effect of the degree of non-financial information disclosure according to the AICGB 63 on values of the banks on Tobin's $q$ scale differs significantly according to differences in levels of growth of the banks. The associated regression model can be written as follows:

\section{Tobin's $\boldsymbol{q}=\mathbf{9 . 6 8 4}+5.202$ NFDisc + 4.741 BGrow - 0.381 (NFDisc * BGrow) + 1.127}

$\mathbf{H}_{\mathbf{0 4}}$ : The effect of the degree of non-financial information disclosure according to the AICGB 63 on values of the banks on Tobin's $q$ scale does not differ significantly $(\alpha=0.05)$ according to differences in levels of financial leverage.

This hypothesis tests for significant differences in effect of non-financial information disclosure on values of the banks on Tobin's $q$ scale according to differences in levels of financial leverage. This hypothesis too was tested using hierarchical interaction regression analysis.

In the first phase of the analysis, the non-financial information disclosure variable was entered. The results (Table 7) revealed that non-financial information disclosure has a statistically-significant effect on values of the banks on Tobin's $q$ scale $(F=9.380$, Sig. $=0.001)$ and that non-financial information disclosure explains $53.8 \%$ of the variations in values of banks.

Table 7. Results of regression analysis of effect of degree of non-financial information disclosure on values of the banks on Tobin's $q$ scale according to differences in levels of financial leverage.

\begin{tabular}{lllllll}
\hline \multirow{2}{*}{ Variable } & \multicolumn{2}{l}{ First Stage } & \multicolumn{2}{l}{ Second Stage } & \multicolumn{2}{c}{ Third Stage } \\
\cline { 2 - 8 } & B & Sig. & \multicolumn{1}{l}{ B } & \multicolumn{1}{l}{ Sig. } & \multicolumn{1}{l}{ B } & \multicolumn{1}{l}{ Sig. } \\
\hline Constant & 12.224 & 0.003 & 6.028 & 0.001 & 8.631 & 0.000 \\
\hline Disclosure of non-financial information & 4.321 & 0.000 & 2.641 & 0.001 & 4.364 & 0.003 \\
\hline Bank size & & & 0.201 & 0.621 & 1.120 & 0.414 \\
\hline Interaction between disclosure and bank size & & & & & 0.412 & 0.514 \\
\hline$R^{2}$ & & 0.538 & & 0.092 & & 0.021 \\
\hline$F$ & 9.380 & & & 0.012 & & 1.029 \\
\hline Sig. & 0.000 & & & 0.621 & & 0.514 \\
\hline Std. Error & 1.420 & & & 1.219 & & 1.011 \\
\hline
\end{tabular}

In the second phase of analysis, the financial leverage variable was entered. The results summarized in Table 6 discern lack of effect of the financial leverage variable on values of the banks on Tobin's $q$ scale $(F=0.012$, Sig. $=0$. 
621).

In the third phase of the analysis, the interaction between non-financial disclosure and financial leverage was entered. The results (Table 7) reveal lack of a statistically-significant effect of that interaction on values of the banks on Tobin's $q$ scale $(F=1.029$, Sig. $=0.514)$. Hence, the alternative hypothesis is accepted, namely, the effect of the degree of non-financial information disclosure according to the AICGB 63 on values of the banks on Tobin's $q$ scale does not differ significantly according to differences in levels of financial leverage. The corresponding regression model can be formulated as follows:

$$
\text { Tobin's } \boldsymbol{q}=8.631+4.364 \text { NFDisc + 1.120 Lev + } 0.412(\text { NFDisc * Lev })+\mathbf{1 . 0 1 1}
$$

$\mathbf{H}_{05}$ : The effect of the degree of non-financial information disclosure according to the AICGB 63 on values of the banks on Tobin's $q$ scale does not differ significantly $(\alpha=0.05)$ according to differences in levels of profitability of the banks.

This hypothesis tests for significant differences in effect of non-financial information disclosure on values of the banks on Tobin's $q$ scale according to differences in levels of profitability of the banks.

Table 8. Results of regression analysis of effect of degree of non-financial information disclosure on values of banks on Tobin's $q$ scale according to differences in levels of profitability of the banks

\begin{tabular}{lllrrrr}
\hline \multirow{2}{*}{ Variable } & \multicolumn{2}{c}{ First Stage } & \multicolumn{2}{c}{ Second Stage } & \multicolumn{2}{c}{ Third Stage } \\
\cline { 2 - 8 } & $\boldsymbol{B}$ & Sig. & \multicolumn{1}{l}{$\boldsymbol{B}$} & \multicolumn{1}{l}{ Sig. } & \multicolumn{1}{l}{$\boldsymbol{B}$} & \multicolumn{1}{c}{ Sig. } \\
\hline Constant & 12.224 & 0.003 & 12.126 & 0.000 & 13.096 & 0.000 \\
\hline Disclosure of non-financial information & 4.321 & 0.000 & 4.840 & 0.000 & 4.980 & 0.001 \\
\hline Bank size & & & 2.654 & 0.000 & 4.650 & 0.000 \\
\hline Interaction between disclosure and bank size & & & & & 1.814 & 0.002 \\
\hline$R^{2}$ & & 0.538 & & 0.521 & & 0.509 \\
\hline$F$ & 9.380 & & & 16.185 & & 18.814 \\
\hline Sig. & 0.000 & & & 0.000 & & 0.002 \\
\hline Std. Error & 1.420 & & & 1.520 & & 1.618 \\
\hline
\end{tabular}

The hypothesis was tested using hierarchical interaction regression analysis in three phases. In the first phase, the non-financial information disclosure variable was entered. The results listed in Table 8 disclose that non-financial information disclosure has statistically-significant effect on values of the banks on Tobin's q scale $(\mathrm{F}=9.380$, Sig. $=$ 0.000 ) and that non-financial information disclosure explains $53.8 \%$ of the variations in values of banks.

In the second phase of the analysis, the bank profitability variable was entered. The results indicate that the bank profitability variable has statistically-significant effect on values of the banks on Tobin's q scale $(\mathrm{F}=16.185$, Sig. $=$ $0.000)$.

In the third phase of analysis, the interaction between non-financial disclosure and bank profitability was entered. The results (Table 8) uncover a statistically-significant effect of that interaction on values of the banks on Tobin's q scale $(\mathrm{F}=18.814$, Sig. $=0.002)$. Thus, the null hypothesis is rejected and the alternative hypothesis is accepted, i.e., the effect of the degree of non-financial information disclosure according to the AICGB 63 on values of the banks on Tobin's q scale differ significantly according to differences in levels of profitability of the banks. The concomitant regression model can be written as follows:

$$
\text { Tobin's } \boldsymbol{q}=13.096+4.980 \mathrm{NFDisc}+4.650 \text { ROA + } 1.814(\text { NFDisc } * \text { ROA })+\mathbf{1 . 6 1 8}
$$

\section{Discussion of the Results}

This study found that the level of non-financial information disclosure amounted to 86.7\%, which is high. Abidance of the banks by the items of non-financial disclosure is attributed to (i) awareness of those banks of non-financial disclosure as an important factor for the financial report users in evaluation of performance of the bank and (ii) reasoning of the instructions and rules related to obligating the banks with the requirements of disclosure. This 
indicates that the non-financial disclosure provides the decision takers with the information that is useful for helping them in taking decisions. This result accorded with the results of the studies of Barakah (2016), Ashoaar et al. (2017), and Alshatnawi (2018), but disagreed with the results of the studies of Assahli (2011), Cohen et al. (2012), and Al-Maryani (2014).

The present study also found that the degree of non-financial information disclosure according to the AICGB 63 has an effect on values of the banks on Tobin's q scale because this facet of disclosure helps the financial report users in knowing the degree of risk surrounding the investments, which increases the investors' trust in the bank and its management and leads to improvement of the market value of the bank. This result agrees with findings of the studies of Dima et al. (2013) and Ashoaar et al. (2015) and disagrees with the results of the studies of Coram (2010), Velazquez et al. (2013), Jahjooh (2017), and Alshatnawi (2018).

This study found that there are differences in the effects of non-financial information disclosure in accordance with the AICGB 63 on values of the banks on Tobin's q scale according to differences in sizes of the banks. The results illustrate that as bank size increases the positive effect of non-financial information disclosure on bank value increases. In addition, interaction between non-financial information disclosure and bank size increases the positive effect of non-financial information disclosure on values of the banks on Tobin's q scale. This coincides with the results of Molayji (2014) and Barakah (2017).

Moreover, the current study found that there are differences in the effects of non-financial information disclosure based on the AICGB 63 on values of the banks on Tobin's q scale according to differences in levels of growth of the banks. The study outcomes underscore that as bank growth increases the positive effect of non-financial information disclosure on bank value increases. Further, interaction between non-financial information disclosure and bank growth increases the positive effect of non-financial information disclosure on values of the banks on Tobin's q scale. Hence, the banks with high growth rates have high investment opportunities. This strengthens the motive for improving the degree of non-financial information disclosure, which reflects on values of the banks.

On the other hand, this study found that there are no differences in the effects of non-financial information disclosure based on the AICGB 63 on values of the banks on Tobin's q scale according to differences in levels of financial leverage. This result can be explained by the fact that most of the financial reliance of the banks is on clients' deposits, which explains why the degree of financial leverage in the sample banks is very high and interest of depositors in non-financial information disclosure is lacking. This finding compares with findings reported by Velazquez et al. (2013), Ashoaar et al. (2015), and Alshatnawi (2018).

Furthermore, this study found that there are differences in the effects of non-financial information disclosure in accordance with AICGB 63 on values of the banks on Tobin's q scale according to differences in levels of bank profitability. This indicates that as bank profitability increases, the positive effect of non-financial information disclosure on the value of the bank increases. As well, the interaction effect of non-financial information disclosure and bank profitability increases the positive influence of non-financial information disclosure on values of the banks on Tobin's q scale. This result accorded with the study of Ashoaar et al. (2015) which pointed to interest of the users of the financial reports in non-financial information disclosure and in achievement of profits and highlighted the role this kind of disclosure has in improving the values of establishments. The present finding, however, disagreed with that of Banghoj and Plenborg (2008).

\section{Recommendations}

The researchers recommend what follows:

1- Expansion of disclosure of non-financial information in the financial reports because this contributes profoundly to an increase in the trust of the stakeholders and reflects positively on the market values of establishments.

2- Prompting the stakeholders to pay attention to non-financial disclosure due to the accurate information it provides that leads to reduction of the state of uncertainty associated with the future growth opportunities and to reinforcement of trust in the financial reports through directing their attention (i.e., that of the stakeholders) to all the items appearing in the financial reports rather than concentrating on the financial indicators only.

3- Activating the role of the central bank in increasing awareness of the banks and financial report users about importance of non-financial disclosure and its role in maximizing the values of the banks.

4- Holding continuous sessions of dialogue between the bank and the investors in the bourse to continually identify and satisfy their information needs.

5- It is necessary that the accounting departments in the universities develop the accounting curricula by including 
the latest occupational releases in them and providing detailed directions about how to apply the Manual of Governance of Companies and Banks, which leads to provision of graduates who are qualified for the sound application of the requirements of corporate governance.

6- Conducting studies that address other characteristics of the banks for their importance, like the age and competitive position of the bank, and investigating their influence on effect of degree of non-financial information disclosure on values of the banks on Tobin's q scale, or performing other studies using other scales than Tobin's q scale for assessment of the market values of banks.

\section{References}

Abdol Gader, D. S. A. (2017). Effect of degree of disclosure of other information accompanying the financial lists on quality of the financial reports: An applied study of the companies listed on the bourse. The First Scientific Conference of the Accounting and Review Department. Faculty of Commerce, Alexandria University, Egypt.

Abdol Naser, E. M. A. (2017). Effect of fulfillment of the companies of the requirements of listing ion the Egyptian index of responsibility (ESG) on value and performance of the company: An applied study. The First Scientific Conference of the Accounting and Review Department. Faculty of Commerce, Alexandria University, Egypt.

Al-Maryani, M. (2014). Testing the Requirements Availability for Disclosure and Transparency in Financial Reporting for Corporate Governance in Emerging Market Economies: The Case of Iraqi Listed Firms. Dirasat, Administrative Sciences, 41(1), 141-153. https://doi.org/10.12816/0007435

Al-Oadat, A. E. S (2015). Effect of disclosure of social responsibility on the market value of the Jordanian commercial banks according to Tobin's Q model: An empirical study of the Jordanian commercial banks 2009-2014. Unpublished master's thesis, The Middle East University, Amman, Jordan.

Alshatnawi, H. M. (2018). Effect of non-financial disclosure on quality of the financial reports and the market value of the Jordanian commercial banks: An applied study. Journal of the Islamic University for Economic and Administrative Studies, 26(3), 124-150. https://doi.org/10.12816/0049876

Annajjar, J. H. (2013). Extent of effect of financial leverage on the financial performance of the public shareholding companies listed on bourse of Palestine: An empirical study. Journal of Al-Azhar University, Gaza, 15(1), 281-318.

Ashoaar, I. N., Zalloom, N. O., \& Khattab, S. A. A. (2015). Role of profitability and indebtedness of the company in determining the effect of level of non-financial disclosure on the market value. Jordan Journal of Business Administration, 11(3), 685-703.

Ashshahed, R. M., \& Al-Anati, R. M. (2017). Effects of ownership structure and characteristics of the banks on quality of profits: An empirical study of the Jordanian commercial banks. Al-Mithqal Journal for Economical and Administrative Sciences, 3(2), 311-345.

Assahli, M. (2011). Index of transparency and disclosure in the Saudi companies. Journal of Accounting Research, $10(2), 11-42$.

Bachoo, K., Tan, R., \& Wilson, M. (2013). Firm Value and the Quality Sustainability Reporting in Australia. Australian Accounting Review, 23(1), 67-87. https://doi.org/10.1111/j.1835-2561.2012.00187.x

Banghoj, J., \& Plenborg, T. (2008). Value relevance of voluntary disclosure in the annual report. Accounting and Finance, 48(2), 159-180. https://doi.org/10.1111/j.1467-629X.2007.00240.x

Barakah, M. N. H. (2016). Factors determining the level of non-financial disclosure of the commercial banks listed on Amman Stock Exchange Market. Unpublished master's thesis, Zarqa University, Jordan.

Binh, T. (2012). Voluntary Disclosure Information in the Annual Reports of Non-Financial Listed Companies: The Case of Vietnam. Journal of Applied Economics and Business Research, 2(2), 69-90.

Bonna, A. K. (2012). The Impact of Corporate Governance on Corporate Financial Performance. Unpublished thesis, Walden University: USA.

Central Bank of Jordan. (2018). Retrieved from http://www.cbj.gov.jo/

Cohen, J., Holder-Webb., L. L., Nath, L., \& Wood, D. (2012). Corporate Reporting of Nonfinancial Leading Indicators of Economic Performance and Sustainability. Accounting Horizons, 26(1), 65-90. https://doi.org/10.2308/acch-50073

Coram, P. (2010). The Effect of Investor Sophistication on the Influence of Non-financial Performance Indicators on 
$\begin{array}{llll}\text { Investors Judgments. } & \text { Accounting } & \text { 263-280. }\end{array}$ https://doi.org/10.1111/j.1467-629X.2009.00328.x

Dima, B., Cuzman, I., Dima, S., \& Saramat, O. (2013). Effects of Financial and Non-Financial Information Disclosure on Prices' Mechanisms for Emergent Markets: The Case of Romanian Bucharest Stock Exchange. Accounting and Management Information Systems, 12(1), 76-100.

Field, A. (2005). Discovering Statistics Using SPSS and sex drugs and rock ' $n$ ' roll (2nd ed.). London California New Delhi: SAGE Publications.

Flostrand, P., \& Strom, N. (2006). The Valuation Relevance of Non-Financial Information. Management Research News, 29(9), 580-597. https://doi.org/10.1108/01409170610709014

Grewal, J., Riedl, E., \& Serafeim, G. (2015). Market Reaction to mandatory Non-financial Disclosure. SSRN, 15(1), 1-15. https://doi.org/10.2139/ssrn.2657712

Hahn, R., \& Michael, K. (2013). Determinants of Sustainability Reporting: A review of Results, Trends, Theory and Opportunities in an Expanding Field of Research. Journal of Cleaner Production, 59, 5-21. https://doi.org/10.1016/j.jclepro.2013.07.005

Hair, J., Black, W, Babin, B., \& Anderson, R. (2010). Multivariate Data Analysis: A global Perspective (7th ed.).

Haji, A. A., \& Hossain, D. M. (2016). Exploring the implications of integrated reporting on organizational reporting practice Evidence from highly regarded integrated reporters. Qualitative Research in Accounting \& Management, 13(4). https://doi.org/10.1108/QRAM-07-2015-0065

Hossain, M. (2008). The extent of disclosure in annual reports of banking companies: The case of India. European Journal of Scientific Research, 23(4), 659-680.

Imam, S., Chan, J., \& Ali Shah, S. Z. (2013, June). Equity valuation models and target price accuracy in Europe: Evidence from equity reports. International Review of Financial Analysis, 28, 9-19. https://doi.org/10.1016/j.irfa.2013.02.008

Jahjooh, M. M. (2017). Effect of non-financial disclosure on on the market value of the companies listed on bourse of Palestine: A field study. Unpublished master's thesis, the Islamic University.

Kareem, A. M. (2014). Effect of the accounting performance measures on value of the establishment: An applied study on the industrial public shareholding companies in Jordan. Al-Hikma Magazine, 22.

Liew, C., Alfan, E., \& Devi, S. (2015). Family firms, expropriation and firm value: evidence from related party transactions in Malaysia. The Journal of Developing Areas, 49(5), 139-152. https://doi.org/10.1353/jda.2015.0048

Molayji, M. M. A. (2014). Effect of shift to the international financial reports standards on quality of the accounting information and values of the companies listed in the Saudi business environment: An applied theoretical study. Journal of Accounting and Auditing, 2(2), 1-50.

Omar B., \& Simon, J. (2011). Corporate Aggregate Disclosure Practices in Jordan. Advances in Accounting, 27, 166-186. https://doi.org/10.1016/j.adiac.2011.05.002

Omar, B., Al Shaar, E., \& Zalloum, N. (2014). The Effect of Social Responsibility Accounting Disclosure on the Financial Performance of Jordanian Industrial Companies. Dirasat, Administrative Sciences, 41(2), 240-258.

Radebaugh, L. H., \& Gray, S. (2001). International Accounting and Multinational Enterprises (5th ed., p. 296). New York: John Wiley and Sons, Inc.

Talkhan, S. M. A. (2017). Effect of size of the accounting and review establishment on the relationship between the accounting information generated according to the international financial report standards and company value: An applied study. The First Scientific Conference of the Accounting and Review Department, Faculty of Commerce, Alexandria University.

Tjia, O., \& Setiawati, L. (2012). Effect of CSR Disclosure to Value of the Firm: Study for Banking Industry in Indonesia. World Journal of Social Sciences, 2(6), 169-178.

Velazquez, M., Callen, Y., Fernandez, B., \& Uribe, M. (2013). Impact of Disclosure of Financial Information in Latin-American Companies. Global Conference on Business and Finance Proceedings, 8(1), 771-781.

Yuen, C., Liu, M., Zhang, X., \& Lu, C. (2009). A Case Study of voluntary Disclosure by Chinese enterprises. Asian 
Journal of Finance and Accounting, 1(2), 118-145. https://doi.org/10.5296/ajfa.v1i2.121

Zalloom, N. O. (2013). Disclosure of commitment with application of the guiding rules specific to governance of companies and its effect on value of the company. Journal of the Islamic University for Economic and Administrative Studies, 2(21), 163-187.

\section{Appendix}

Appendix (I): Index of Non-financial Information Disclosure

\begin{tabular}{|c|c|}
\hline Number & Item \\
\hline 1. & Organizational Structure of the Bank. \\
\hline 2. & Tasks of the committees of the Board of Directors of the bank. \\
\hline 3. & Responsibilities of the committees of the Board of Directors of the bank. \\
\hline 4. & $\begin{array}{l}\text { Authorities mandated by the Management Council to the committees of the Board of Directors of } \\
\text { the bank. }\end{array}$ \\
\hline 5. & $\begin{array}{l}\text { Disclosure of the information which concern the stakeholders and which are shown in the Bank } \\
\text { Institutional Governance Manual. }\end{array}$ \\
\hline 6. & $\begin{array}{l}\text { Disclosure of the level of commitment of the bank with content of the Bank Institutional } \\
\text { Governance Manual. }\end{array}$ \\
\hline 7. & Information on qualifications of every member of the Management Council. \\
\hline 8. & Information on experiences of every member of the Management Council. \\
\hline 9. & $\begin{array}{l}\text { Information on extent of contribution of every member of the Management Council in the capital } \\
\text { of the bank. }\end{array}$ \\
\hline 10. & Information on every member of the Management Council, whether she/he is independent or not. \\
\hline 11. & $\begin{array}{l}\text { Information about every member of the Management Council in terms of her/his membership in } \\
\text { the committees of the Board of Directors of the bank. }\end{array}$ \\
\hline 12. & $\begin{array}{l}\text { Information about every member of the Management Council in terms of her/his appointment } \\
\text { date. }\end{array}$ \\
\hline 13. & $\begin{array}{l}\text { Information about the memberships which each of the members of the Management Council } \\
\text { occupy in the management councils of other companies. }\end{array}$ \\
\hline 14. & $\begin{array}{l}\text { Information about the loans endowed by the bank to each member of the Management Council in } \\
\text { the bank. }\end{array}$ \\
\hline 15. & $\begin{array}{l}\text { Information about every member of the Management Council regarding any other transactions } \\
\text { that took place between the bank and the member or the parties related to her/him. }\end{array}$ \\
\hline 16. & Information about the Department of Risk Management in terms of its structure. \\
\hline 17. & Information about the Department of Risk Management in terms of nature of its operations. \\
\hline 18. & Information about the Department of Risk Management in terms of intervening developments. \\
\hline 19. & Disclosure of the number of times of meeting of the Management Council. \\
\hline 20. & $\begin{array}{l}\text { Disclosure of the number of times of meeting of the committees of the Board of Directors of the } \\
\text { bank. }\end{array}$ \\
\hline 21.. & $\begin{array}{l}\text { Disclosure of the number of times of presence of every Management Council member in the } \\
\text { meetings. }\end{array}$ \\
\hline 22. & $\begin{array}{l}\text { Disclosure of the number of times of presence of every member of the committees of the Board } \\
\text { of Directors of the bank in the meetings. }\end{array}$ \\
\hline
\end{tabular}


23. Disclosure of the names of every member of the Management Council resigning during the year.

24. Disclosure of the names of every member of the Senior Executive Management resigning during the year.

25. A summary of the reward-granting policy in the bank.

26. Disclosure of all forms of rewards granted to the members of the Management Council, each separately, in the previous year.

27. Disclosure of all forms of rewards granted to the members of the Senior Executive Management, each separately, in the previous year.

28. Disclosure of the names of the shareholders possessing 1.0\% or more of the capital of the bank.

29. Disclosure of the ultimate beneficiary of these inputs or any part of it.

30. Disclosure of whether any of these inputs is partially or totally mortgaged.

31. Statement from every council member that she/he did not obtain any benefits through her/his work in the bank in the past year which she/he did not disclose.

32. Disclosure of the responsibility of the bank for accuracy and adequacy of the financial information of the bank and the information appearing in the report.

33. Disclosure of the responsibility of the council for confirming adequacy of the internal control and monitoring systems. 